\title{
Dietary fructose $v$. glucose lowers ferrous-iron absorption in rats
}

\author{
BY I. A. BROUWER ${ }^{1,2}$, A. G. LEMMENS ${ }^{2}$ AND A. C. BEYNEN ${ }^{1,2}$ \\ ${ }^{1}$ Department of Human Nutrition, Agricultural University, PO Box 8129, 6700 EV Wageningen, \\ The Netherlands and ${ }^{2}$ Department of Laboratory Animal Science, State University, PO Box 80.166, \\ 3508 TD Utrecht, The Netherlands
}

(Received 19 February 1992 - Accepted 7 September 1992)

\begin{abstract}
The effect of dietary fructose $v$. glucose on Fe solubility in the small intestine and apparent Fe absorption was studied in rats. Female rats were fed for 4 weeks on low-Fe $(10 \mathrm{mg} \mathrm{Fe} / \mathrm{kg})$ or normal-Fe (40 mg $\mathrm{Fe} / \mathrm{kg}$ ) diets containing either fructose or glucose $(709 \cdot 4 \mathrm{~g}$ monosaccharide $/ \mathrm{kg})$. Fe was added to the diets in the form of $\mathrm{FeSO}_{4}$. The low-Fe diets did not lower levels of haemoglobin and packed cell volume, but significantly lowered $\mathrm{Fe}$ concentration and $\mathrm{Fe}$ mass in the liver, kidney and spleen. Fructose v. glucose also lowered $\mathrm{Fe}$ concentrations in these organs, but did not alter absolute Fe contents. Low Fe intake reduced the amount of $\mathrm{Fe}$ in the intestinal lumen. The total amount of $\mathrm{Fe}$ and $\mathrm{Fe}$ concentration in the liquid phase of the proximal intestinal lumen were depressed by fructose irrespective of Fe intake. Fructose also lowered the amount of $\mathrm{Fe}$ in the liquid phase of the distal intestine. In keeping with these observations, dietary fructose significantly lowered apparent absorption of $\mathrm{Fe}$ at the two levels of $\mathrm{Fe}$ intake. Decreasing the intake of $\mathrm{Fe}$ raised the percentage of apparent $\mathrm{Fe}$ absorption.
\end{abstract}

Fructose: Iron: Glucose: Rat

Under in vitro conditions at neutral to alkaline $\mathrm{pH}$, fructose can form with $\mathrm{Fe}^{3+}$ a stable, soluble chelate (Charley et al. 1963). In guinea-pigs, Fe absorption from the orally administered $\mathrm{Fe}^{3+}$-fructose complex was more efficient than that from $\mathrm{FeSO}_{4}$ (Bates et al. 1972). In a feeding trial with rats, sucrose $v$. maize starch raised Fe absorption (Johnson \& Hove, 1986). When giving Fe-depleted rats a single meal containing ${ }^{59} \mathrm{FeCl}_{3}$ and either fructose or glucose, fructose was found to stimulate Fe absorption (Pabón de Rozo et al. 1986). Thus, fructose in the diet may enhance Fe absorption. In contrast, the influence of fructose on $\mathrm{Fe}$ stores in the liver is not clear. Fructose $v$ glucose either lowered (Landes, 1975; Fields et al. 1984) or raised (Landes, 1975) the amount of Fe in the liver of rats. Fructose $v$. starch either lowered (Fields et al. 1984) or did not influence (Holbrook et al. 1986) the absolute amount of $\mathrm{Fe}$ in the liver.

In the present experiment with rats the effect of dietary fructose on Fe solubility in the small intestine was investigated. It was hypothesized that in rats fed on fructose instead of glucose there is more soluble $\mathrm{Fe}$ in the ileal lumen due to formation of the complex. This would explain the earlier observed (Bates et al. 1972; Pabón de Rozo et al. 1986) stimulatory effect of fructose on $\mathrm{Fe}$ absorption because soluble rather than insoluble $\mathrm{Fe}$ in the ileal lumen is absorbed (Hallberg, 1981). We also determined the effect of fructose on apparent $\mathrm{Fe}$ absorption and on $\mathrm{Fe}$ stores in the liver.

\section{MATERIALS AND METHODS}

Animals, housing and diets

Female Wistar ( $\mathrm{Cpb}: \mathrm{WU}$ ) rats, aged about 7 weeks, were used. The rats were derived from the colony of the Laboratory Animals Centre of the Wageningen Agricultural University. 
Table 1. Composition of the diets

\begin{tabular}{|c|c|c|c|c|}
\hline \multirow[t]{2}{*}{ Diet ... } & \multicolumn{2}{|c|}{ Normal-Fe } & \multicolumn{2}{|c|}{ Low-Fe } \\
\hline & Glucose $\dagger$ & Fructose & Glucose & Fructose \\
\hline \multicolumn{5}{|l|}{ Ingredients } \\
\hline Glucose $(\mathrm{g})$ & $709 \cdot 4$ & - & $709 \cdot 4$ & - \\
\hline Fructose (g) & - & $709 \cdot 4$ & - & $709 \cdot 4$ \\
\hline $\mathrm{FeSO}_{4} \cdot 7 \mathrm{H}_{2} \mathrm{O}(\mathrm{mg})$ & 174 & 174 & $17 \cdot 4$ & $17 \cdot 4$ \\
\hline Constant components* $(\mathrm{g})$ & 290.6 & $290 \cdot 6$ & $290 \cdot 6$ & $290 \cdot 6$ \\
\hline \multicolumn{5}{|l|}{ Chemical analysis } \\
\hline $\mathrm{Fe}(\mathrm{mg} / \mathrm{kg})$ & $42 \cdot 0$ & $38 \cdot 8$ & $9 \cdot 5$ & $9 \cdot 0$ \\
\hline
\end{tabular}

* The constant components consisted of $(\mathrm{g})$ : casein 151 , maize oil 25 , coconut fat 25 , cellulose $30, \mathrm{CaCO}_{3}$ $12 \cdot 4, \mathrm{NaH}_{2} \mathrm{PO}_{4} \cdot 2 \mathrm{H}_{2} \mathrm{O} 15 \cdot 1, \mathrm{MgCO}_{3} 1 \cdot 4, \mathrm{KCl} \mathrm{l} \cdot 0, \mathrm{KHCO}_{3} 7 \cdot 7, \mathrm{Fe}$-free mineral premix 10, vitamin premix 12. The mineral premix consisted of $(\mathrm{mg}): \mathrm{MnO}_{2} 79, \mathrm{ZnSO}_{4} . \mathrm{H}_{2} \mathrm{O} 33, \mathrm{NiSO}_{4} \cdot 6 \mathrm{H}_{2} \mathrm{O} 13, \mathrm{NaF} 2, \mathrm{KI} 0 \cdot 2, \mathrm{CuSO}_{4} .5 \mathrm{H}_{2} \mathrm{O} 15 \cdot 7$, $\mathrm{Na}_{2} \mathrm{SeO}_{3} .5 \mathrm{H}_{2} \mathrm{O} 0 \cdot 3, \mathrm{CrCl}_{3} .6 \mathrm{H}_{2} \mathrm{O} 1 \cdot 5, \mathrm{SnCl}_{2} .2 \mathrm{H}_{2} \mathrm{O} 1 \cdot 9, \mathrm{NH}_{4} \mathrm{VO}_{3} 0 \cdot 2$, maize meal $9853 \cdot 2$. The vitamin premix consisted of $(\mathrm{mg})$ : thiamin 4, riboflavin 3, niacinamide 20 , calcium DL-pantothenate $17 \cdot 8$, pyridoxine 6 , cyanocobalamin 50, choline chloride 2000 , folic acid 1 , biotin 2 , menadione 0.05 , DL- $\alpha$ tocopheryl acetate 60 , retinyl acetate and retinyl palmitate $8(4000 \mathrm{IU})$, cholecalciferol $2(1000 \mathrm{IU})$, maize meal $9826 \cdot 15$.

$\dagger$ This diet also served as the pre-experimental diet.

The rats had been fed ad lib. on a commercial, pelleted diet (RMH-B; Hope Farms, Woerden, The Netherlands) and tap-water.

All rats went through a pre-experimental period of 2 weeks during which they received a purified diet containing $709.4 \mathrm{~g}$ glucose and $40 \mathrm{mg} \mathrm{Fe} / \mathrm{kg}$ (Table 1) and demineralized water. The rats had free access to feed and water. During the pre-experimental period the rats were housed in groups of four animals in stainless-steel cages $(600 \times 210 \times 190 \mathrm{~mm})$ with wire-mesh bases.

At the end of the pre-experimental period (day 0 of the experiment) the rats were divided into four groups of twelve animals each, so that body-weight distributions within the groups were similar. Each group was randomly assigned to one of the purified diets given in Table 1. From day 0 the rats were housed individually in stainless-steel cages $(240 \times 170 \times 170 \mathrm{~mm})$ with wire-mesh bases. The cages were placed in a randomized position in a room with a controlled temperature $\left(20-22^{\circ}\right)$, lighting (light on $07.00-19.00$ hours) and relative humidity $(40-65 \%)$.

During the experimental period one group remained on the diet containing $709.4 \mathrm{~g}$ glucose and $40 \mathrm{mg} \mathrm{Fe} / \mathrm{kg}$. The other groups were fed on diets with either $709.4 \mathrm{~g}$ fructose and $40 \mathrm{mg} \mathrm{Fe} / \mathrm{kg}, 709.4 \mathrm{~g}$ glucose and $10 \mathrm{mg} \mathrm{Fe} / \mathrm{kg}$ or $709.4 \mathrm{~g}$ fructose and $10 \mathrm{mg} \mathrm{Fe} / \mathrm{kg}$. The diet containing $40 \mathrm{mg} \mathrm{Fe} / \mathrm{kg}$ can be considered a normal-Fe diet (National Research Council, 1978), whereas that containing $10 \mathrm{mg} \mathrm{Fe} / \mathrm{kg}$ is a low-Fe diet. The purified diets, which were in powdered form, were stored at $4^{\circ}$ until needed. Feed and demineralized water were provided ad lib. Feed intake and body weights were recorded. The experiment lasted $28-29 \mathrm{~d}$.

\section{Collection of samples}

From day 21 to day 26 the faeces of each rat were collected quantitatively. On day 28 , between 09.00 and 12.00 hours, six rats from each dietary group were anaesthetized in random order by exposure to diethyl ether. Blood was taken by orbital puncture and the anaesthetized rats were immediately killed by decapitation. The entire small intestine between the stomach and the caecum was removed. It was divided into a proximal and a distal half. The digesta of both halves of the intestine were collected separately in 
Table 2. Effect of glucose or fructose on growth performance and organ weights of rats fed on low- and normal-Fe diets $\ddagger$

(Mean values with their pooled standard errors for twelve rats per dietary group)

\begin{tabular}{|c|c|c|c|c|c|c|}
\hline \multirow{2}{*}{$\begin{array}{l}\text { Diet... } \\
\text { Variable }\end{array}$} & \multicolumn{2}{|c|}{ Normal-Fe } & \multicolumn{2}{|c|}{ Low-Fe } & \multirow[b]{2}{*}{ Pooled SE } & \multirow{2}{*}{$\begin{array}{l}\text { Statistical significance } \\
\text { (ANOVA) of effect of } \\
\text { dietary monosaccharide }\end{array}$} \\
\hline & Glucose & Fructose & Glucose & Fructose & & \\
\hline Feed intake $(\mathrm{g} / \mathrm{d})$ & 160 & $14 \cdot 2^{\mathrm{a}}$ & $15 \cdot 6$ & $13 \cdot 9^{\mathrm{a}}$ & 0.92 & $*$ \\
\hline \multicolumn{7}{|l|}{ Body wt (g) } \\
\hline Initial (day 0) & $177 \cdot 1$ & $176 \cdot 7$ & $175 \cdot 4$ & $176 \cdot 1$ & $9 \cdot 4$ & \\
\hline Final (day 28-29) & $217 \cdot 2$ & $214 \cdot 9$ & $217 \cdot 8$ & $206 \cdot 7$ & 13.8 & \\
\hline \multicolumn{7}{|l|}{$\begin{array}{l}\text { Organ wts } \\
(\mathrm{g} / 100 \mathrm{~g} \text { body } w t)\end{array}$} \\
\hline Liver & 3.49 & $4 \cdot 57^{\mathrm{a}}$ & 3.52 & $4 \cdot 46^{\mathrm{a}}$ & 0.26 & $*$ \\
\hline Left kidney & $0 \cdot 32$ & $0 \cdot 38^{a}$ & 0.32 & $0 \cdot 39^{\mathrm{a}}$ & 0.03 & $*$ \\
\hline Right kidney & $0-33$ & $0 \cdot 39^{\mathrm{a}}$ & $0 \cdot 33$ & $0 \cdot 40^{\mathrm{a}}$ & 0.03 & * \\
\hline Heart & $0 \cdot 36$ & $0 \cdot 38$ & 0.36 & $0 \cdot 37$ & 0.02 & * \\
\hline Spleen & $0 \cdot 20$ & $0.22^{a}$ & $0 \cdot 20$ & 0.22 & 0.02 & $*$ \\
\hline
\end{tabular}

a Significantly different from glucose for the same dietary Fe content, $P<0.025$.

$* P<0.05$.

$\dagger$ There were no significant effects of dietary Fe level.

$\ddagger$ For details of diets and procedures, see Table 1 and pp. 171-172.

preweighed centrifuge tubes by gently squeezing the intestine between finger and thumb, and total weight was determined. The digesta were immediately centrifuged $(10 \mathrm{~min}$, $10000 \mathrm{~g}$ ) at room temperature, and the supernatant fraction and pellet were separated. The weights of the pellet and supernatant fraction were determined; $\mathrm{pH}$ of the supernatant fraction was measured promptly with an electrode (Russell combination $\mathrm{pH}$ electrode, Type RS-53, Auchtermuchty, Fife). The heart, kidneys, liver, spleen and tibia were excised, weighed and frozen at $-20^{\circ}$. On day 29 the entire procedure was repeated with the remaining rats.

\section{Chemical analysis}

In whole heparinized blood, haemoglobin and packed cell volume were measured using a Sysmex K1000 (Automated Hematology Analyzer; Toa Medical Electronics Co. Ltd, Kobe, Japan). Trichloroacetic acid (TCA) was added to the supernatant fraction to a final concentration of $50 \mathrm{~g} / 1$ and the TCA-soluble fraction isolated by centrifugation $(2 \mathrm{~min}$, $10000 \mathrm{~g})$. The pellet of whole digesta was freeze-dried overnight, weighed, ashed $\left(500^{\circ}\right.$ for $17 \mathrm{~h}$ ) and dissolved in $0.1 \mathrm{ml} 6 \mathrm{M}-\mathrm{HCl}$ and $0.9 \mathrm{ml}$ demineralized water. $\mathrm{Fe}$ in intestinal fractions, plasma $\mathrm{Fe}$, total $\mathrm{Fe}$-binding capacity and transferrin saturation were determined using a commercial kit (Iron FZ Test; Roche, Roche Diagnostics, Basel, Switzerland) and a COBAS-BIO auto-analyzer (Hoffmann-La Roche BV, Mijdrecht, The Netherlands). Cholesterol and triacylglycerols in plasma were determined enzymically using kits purchased from Roche Diagnostics and the COBAS-BIO auto-analyzer.

The heart, kidneys, spleen and tibia were dried overnight $\left(105^{\circ}\right)$, weighed and ashed $\left(500^{\circ}, 17 \mathrm{~h}\right)$. The ash was dissolved in $1 \mathrm{ml} 6 \mathrm{M}-\mathrm{HCl}$ and $4 \mathrm{ml}$ demineralized water. Fe in the liver was measured after wet-ashing with $14 \mathrm{M}$-nitric acid. Fe in the feed was determined after wet-ashing: $5 \mathrm{~g}$ feed was dissolved in $5 \mathrm{ml} 18 \mathrm{M}-\mathrm{H}_{2} \mathrm{SO}_{4}$ and $14 \mathrm{M}-\mathrm{HNO}_{3}$ and heated at $120^{\circ}$ until a clear solution was obtained. Appropriate dilutions were made for the determination of Fe by atomic absorption spectrometry (Varian AA-475; Varian Techtron, Springvale, Australia). 


\section{Calculations}

The distribution of Fe between the solid and liquid phases of digesta was calculated. The pellet obtained after centrifugation of whole digesta contains the solid phase contaminated with the liquid phase. The weight of the solid phase was obtained after freeze-drying the pellet. The weight of the liquid phase was calculated as the sum of weights of the liquid phase in the pellet (total pellet weight minus solid phase) and supernatant fraction. The concentration of $\mathrm{Fe}$ in the supernatant fraction was taken for that in the liquid phase. The amount of $\mathrm{Fe}$ in the solid phase was calculated as that in the total pellet minus that in the liquid phase of the pellet. Multiplying Fe concentration $(\mu \mathrm{g} / \mathrm{g})$ in the supernatant fraction by the weight of the liquid phase gave the amount of $\mathrm{Fe}$ in the liquid phase.

The proportion of $\mathrm{Fe}$ in the liquid phase was computed as the percentage of total $\mathrm{Fe}$ in intestinal contents. Apparent digestibility of $\mathrm{Fe}$ was calculated as intake minus faecal excretion and expressed as a percentage of intake.

\section{Statistical analysis}

Treatment effects were statistically evaluated by two-way analysis of variance. The probability of a type 1 error $P<0.05$ was taken as the criterion of significance. The effects of fructose $v$. glucose with Fe constant and the effects of dietary Fe concentration with sugar constant were statistically analysed using Student's $t$ test and Bonferroni's adaptation; the level of significance was pre-set at $P<0.025$. Data were analysed by computer using the SPSS/PC + statistical package.

\section{RESULTS}

Feed intakes were significantly lower in rats fed on the fructose diets, but final body weights did not differ between the experimental groups (Table 2). Fructose increased the weights of liver, kidney, heart and spleen. The livers of rats fed on the fructose diets had a greywhite appearance. Fructose $v$. glucose in the diet did not affect plasma cholesterol, but produced hypertriacylglycerolaemia. Plasma cholesterol and triacylglycerol concentrations for rats fed on the glucose and fructose diets were: $2 \cdot 16$ (SE 0.22) and 2.36 (SE 0.22), and 0.78 (SE 0.24) and 1.14 (SE 0.43) mM, ( $n$ 24). The amount of Fe in the diet did not influence plasma lipids.

Haemoglobin and packed cell volume values were not influenced by the type of monosaccharide or the amount of $\mathrm{Fe}$ in the diet (Table 3). Decreasing the amount of $\mathrm{Fe}$ in the diet lowered the plasma Fe concentration and transferrin saturation. Fructose $v$. glucose in the diet slightly, but significantly, elevated total Fe-binding capacity and reduced transferrin saturation.

In all organs except the heart, Fe concentrations were significantly lowered in rats fed on the low-Fe diets (Table 3). Fructose $v$. glucose had a similar effect and also reduced heart $\mathrm{Fe}$ concentrations. For tibia Fe, the lowering effect of fructose failed to reach statistical significance. Looking at the Fe mass in organs it is clear that the low-Fe diets reduced $\mathrm{Fe}$ in the liver, kidney and spleen. However, fructose did not lower Fe mass in the liver, kidney and spleen. For kidney there was even a slight increasing effect.

Fructose significantly reduced the weight of the liquid and solid phase in the proximal half of the small intestine (Table 4). In the distal half such fructose effects were not seen. Fructose significantly raised the $\mathrm{pH}$ of the liquid phase of the proximal intestine, but not that of the distal intestine. The total amount of $\mathrm{Fe}$ and Fe concentration in the liquid phase of the proximal intestine were depressed by fructose. Fructose instead of glucose in the diet also lowered the amount of $\mathrm{Fe}$ in the liquid phase of the distal intestine, but did not affect Fe concentration. Low Fe intake reduced the amount and concentration of $F e$ in the liquid 
Table 3. Effect of glucose or fructose on blood Fe variables and tissue Fe of rats fed on low- and normal-Fe diets $\$$

(Mean values with their pooled standard errors for twelve rats per dietary group)

\begin{tabular}{|c|c|c|c|c|c|c|c|}
\hline \multirow{3}{*}{$\begin{array}{l}\text { Diet... } \\
\text { Variable }\end{array}$} & \multirow{2}{*}{\multicolumn{2}{|c|}{ Normal-Fe }} & \multirow{2}{*}{\multicolumn{2}{|c|}{ Low-Fe }} & \multirow[b]{3}{*}{ Pooled SE } & \multicolumn{2}{|c|}{$\begin{array}{l}\text { Statistical significance } \\
\text { (ANOVA) of effect of: }\end{array}$} \\
\hline & & & & & & \multirow{2}{*}{$\begin{array}{c}\text { Dietary } \\
\text { monosaccharide }\end{array}$} & \multirow{2}{*}{$\begin{array}{l}\text { Dietary } \\
\text { Fe level }\end{array}$} \\
\hline & Glucose & Fructose & Glucose & Fructose & & & \\
\hline \multicolumn{8}{|l|}{ Blood } \\
\hline Haemoglobin $(\mathrm{mmol} / \mathrm{l})$ & $9 \cdot 31$ & $9 \cdot 17$ & $9 \cdot 19$ & 9.07 & $0 \cdot 02$ & & \\
\hline Packed cell volume & 0.47 & 0.46 & $0 \cdot 45$ & 0.46 & 0.003 & & \\
\hline Plasma Fe $(\mu \mathrm{mol} / 1)$ & $56 \cdot 31$ & $59 \cdot 66$ & $54 \cdot 13$ & $49 \cdot 15^{\mathrm{b}}$ & $8 \cdot 57$ & & $*$ \\
\hline $\begin{array}{l}\text { Total Fe-binding } \\
\text { capacity }(\mu \mathrm{mol} / 1)\end{array}$ & $92 \cdot 32$ & $105 \cdot 3^{\mathrm{a}}$ & $96 \cdot 33$ & $105 \cdot 7$ & $11 \cdot 24$ & $*$ & \\
\hline $\begin{array}{l}\text { Transferrin } \\
\text { saturation }(\%)\end{array}$ & 61.99 & $57 \cdot 49$ & $56 \cdot 41$ & $47 \cdot 23^{\mathrm{abs}}$ & $10 \cdot 97$ & * & $*$ \\
\hline \multicolumn{8}{|l|}{ Tissue $\mathrm{Fe}(\mu \mathrm{g} / \mathrm{g}$ dry wt) } \\
\hline Liver & 772 & $535^{\mathrm{a}}$ & $464^{b}$ & $380^{\mathrm{b}}$ & $112 \cdot 6$ & * & * \\
\hline Kidney & 309 & $269^{a}$ & $244^{\mathrm{b}}$ & 245 & $35 \cdot 0$ & $*$ & $*$ \\
\hline Spleen & 2848 & 2210 & $1675^{\mathrm{b}}$ & $1561^{b}$ & 632.9 & $*+$ & $*+$ \\
\hline Heart & 422 & $363^{a}$ & 369 & 365 & $48 \cdot 4$ & $*$ & \\
\hline Tibia & $74 \cdot 6$ & $66 \cdot 1$ & $61 \cdot 1^{b}$ & $56 \cdot 5$ & $13 \cdot 6$ & & * \\
\hline \multicolumn{8}{|l|}{ Tissue Fe ( $\mu \mathrm{g} /$ organ $)$} \\
\hline Liver & 1875 & 1805 & $1146^{\mathrm{b}}$ & $1162^{b}$ & $274 \cdot 0$ & & $*$ \\
\hline Kidney & 108 & 111 & $83^{\mathrm{b}}$ & $87^{\mathrm{b}}$ & 11.9 & $*+$ & $* \dagger$ \\
\hline Spleen & 281 & 231 & $164^{b}$ & $158^{b}$ & $69 \cdot 0$ & & $* \dagger$ \\
\hline Heart & $74 \cdot 5$ & $65 \cdot 4$ & $64 \cdot 4$ & $63 \cdot 0$ & 112 & & \\
\hline
\end{tabular}

a Significantly different from glucose for the same dietary Fe content, $P<0.025$.

b Significantly different from normal Fe for the same dietary monosaccharide, $P<0.025$.

* $P<0 \cdot 05$.

$\dagger$ After log-transformation of the data (unadjusted pooled standard errors are given)

\$For details of diets and procedures, see Table 1 and pp. 171-173.

and solid phases of both the proximal and distal halves of the intestine, but increased the proportion of $\mathrm{Fe}$ in the liquid phase. There were no interactions between the effects of fructose and $\mathrm{Fe}$.

Intake of $\mathrm{Fe}$ was significantly lower for groups fed on fructose instead of glucose and for groups fed on a low-Fe diet $v$. a high-Fe diet (Table 5). Faecal output of Fe was depressed in rats given the low-Fe diets, but not in rats fed on the fructose diets. Fructose $v$. glucose caused a significantly decreased absorption of Fe. The low-Fe diets raised the percentage of apparent $\mathrm{Fe}$ absorption.

\section{DISCUSSION}

Lowering $\mathrm{Fe}$ intake in rats generally produces reduced values for haemoglobin and packed cell volume (Sørensen, 1965; Wien \& Van Campen, 1991). This was not seen in the present experiment and may have been related to the somewhat advanced age of the animals (7 weeks at the beginning of the experiment). Possibly the Fe stores were sufficiently large to prevent changes in haemoglobin and packed cell volume after feeding the low-Fe diets for 4 weeks. The rats fed on the low-Fe diets did show other signs of Fe deficiency, such as lowering of $\mathrm{Fe}$ in the liver, kidney, spleen, tibia and a slight decrease of plasma $\mathrm{Fe}$ and transferrin saturation. 
Table 4. Effect of glucose or fructose on the distribution of $\mathrm{Fe}$ between liquid and solid phases of digesta in small intestine of rats fed on low-or normal-Fe dietsł

(Mean values with their pooled standard errors for twelve rats per dietary group)

\begin{tabular}{|c|c|c|c|c|c|c|c|}
\hline \multirow{3}{*}{$\begin{array}{l}\text { Diet... } \\
\text { Variable }\end{array}$} & \multirow{2}{*}{\multicolumn{2}{|c|}{ Normal-Fe }} & \multirow{2}{*}{\multicolumn{2}{|c|}{ Low-Fe }} & \multirow[b]{3}{*}{ Pooled SE } & \multicolumn{2}{|c|}{$\begin{array}{l}\text { Statistical significance } \\
\text { (ANOVA) of effect of: }\end{array}$} \\
\hline & & & & & & \multirow{2}{*}{$\begin{array}{c}\text { Dietary } \\
\text { monosaccharide }\end{array}$} & \multirow{2}{*}{$\begin{array}{l}\text { Dietary } \\
\text { Fe level }\end{array}$} \\
\hline & Glucose & Fructose & Glucose & Fructose & & & \\
\hline \multicolumn{8}{|l|}{ Proximal intestine } \\
\hline \multicolumn{8}{|l|}{ Liquid phase } \\
\hline Wt $(\mathrm{g})$ & 0.23 & $0 \cdot 14^{\mathrm{a}}$ & 0.27 & $0 \cdot 18^{\mathrm{a}}$ & $0 \cdot 10$ & * & \\
\hline $\mathrm{pH}$ & 6.04 & $6 \cdot 52$ & $6 \cdot 12$ & 6.43 & 0.52 & * & \\
\hline Solid phase wt $(\mathrm{g})$ & 0.04 & $0.02^{\mathrm{a}}$ & 0.06 & 0.03 & 0.02 & * & \\
\hline \multicolumn{8}{|l|}{$\mathrm{Fe}$ : } \\
\hline $\begin{array}{l}\text { Amount in liquid } \\
\text { phase }(\mu \mathrm{g})\end{array}$ & $1 \cdot 58$ & 0.69 & $0.55^{\mathrm{b}}$ & $0 \cdot 31^{a b}$ & 0.68 & $* \dagger$ & $* \dagger$ \\
\hline $\begin{array}{l}\text { Amount in solid } \\
\text { phase }(\mu \mathrm{g})\end{array}$ & $11 \cdot 0$ & $7 \cdot 20$ & $2 \cdot 07^{\mathrm{b}}$ & $1.59^{\mathrm{b}}$ & $4 \cdot 25$ & & $* \dagger$ \\
\hline $\begin{array}{l}\text { Percentage in liquid } \\
\text { phase }(\%)\end{array}$ & $13 \cdot 0$ & $13 \cdot 3$ & $22 \cdot 2^{\mathrm{b}}$ & $18 \cdot 6$ & $8 \cdot 30$ & & * \\
\hline $\begin{array}{l}\text { Concentration in } \\
\text { liquid phase }(\mu \mathrm{g} / \mathrm{g})\end{array}$ & $6 \cdot 56$ & $5 \cdot 00$ & $1.98^{\mathrm{b}}$ & $1.75^{\mathrm{b}}$ & 1.42 & $* \dagger$ & $* \dagger$ \\
\hline \multicolumn{8}{|l|}{ Distal intestine } \\
\hline \multicolumn{8}{|l|}{ Liquid phase } \\
\hline Wt $(\mathrm{g})$ & 0.44 & 0.37 & 0.44 & 0.40 & $0 \cdot 11$ & & \\
\hline $\mathrm{pH}$ & 7.72 & 7.79 & $7 \cdot 52$ & 7.62 & $0-31$ & & * \\
\hline Solid phase wt (g) & $0 \cdot 12$ & $0 \cdot 10$ & $0 \cdot 11$ & 0.11 & 0.04 & & \\
\hline \multicolumn{8}{|l|}{ Fe: } \\
\hline $\begin{array}{l}\text { Amount in liquid } \\
\text { phase }(\mu \mathrm{g})\end{array}$ & $1 \cdot 27$ & 1.04 & $0 \cdot 69^{\mathrm{b}}$ & $0.55^{b}$ & $0-30$ & $*$ & $*$ \\
\hline $\begin{array}{l}\text { Amount in solid } \\
\text { phase }(\mu \mathrm{g})\end{array}$ & $50 \cdot 2$ & $41 \cdot 4$ & $7 \cdot 8^{\mathrm{h}}$ & $8 \cdot 2^{b}$ & $12 \cdot 55$ & & $* \dagger$ \\
\hline $\begin{array}{l}\text { Percentage in liquid } \\
\text { phase }(\%)\end{array}$ & $2 \cdot 60$ & 3.01 & $8 \cdot 59^{\mathrm{b}}$ & $6.99^{b}$ & $2 \cdot 66$ & & $* \dagger$ \\
\hline $\begin{array}{l}\text { Concentration in } \\
\text { liquid phase }(\mu \mathrm{g} / \mathrm{g})\end{array}$ & 2.93 & $2 \cdot 85$ & $1 \cdot 51^{\mathrm{b}}$ & $1 \cdot 38^{\mathrm{h}}$ & 0.48 & & * \\
\hline
\end{tabular}

a Significantly different from glucose for the same dietary Fe content, $P<0.025$.

b Significantly different from normal Fe for the same dietary monosaccharide, $P<0 \cdot 025$.

* $P<0.05$.

$\uparrow$ After log-transformation of the data (unadjusted pooled standard errors are given).

\$ For details of diets and procedures, see Table 1 and pp. 171-174.

It is known that fructose in the diet enlarges the liver of rats (Landes, 1975; Fields et al. 1984; Holbrook et al. 1986; Lewis et al. 1990). In the present experiment this was also found. Fructose reduced the concentration of $\mathrm{Fe}$ in the liver, but did not affect the total hepatic Fe content. In previous studies with rats fructose $v$. glucose either lowered (Fields et al. 1984; Landes, 1975) or raised (Landes, 1975) the absolute amount of $\mathrm{Fe}$ in the liver. Thus, fructose has no systematic influence on Fe stores in the liver.

Fructose $v$. glucose reduced the total amount of $\mathrm{Fe}$ in the small intestine. This fructose effect could result from an altered feed intake pattern of the rats given fructose or from an altered flow of digesta through the small intestine. The reduced food intake by rats given fructose may have contributed to the observed reduction in intestinal Fe content. Fructose also lowered the concentration of $\mathrm{Fe}$ in the liquid phase of small intestinal contents. As it has been suggested that only soluble Fe may cross the intestinal epithelium (Hallberg, 
Table 5. Effect of glucose or fructose on apparent absorption of Fe in rats fed on low- and normal-Fe diets ${ }^{\dagger}$

(Mean values with their standard errors for twelve rats per dietary group*)

\begin{tabular}{|c|c|c|c|c|c|c|c|c|}
\hline \multirow{3}{*}{$\begin{array}{l}\text { Diet... } \\
\text { Fe balance }\end{array}$} & \multicolumn{4}{|c|}{ Normal-Fe } & \multicolumn{4}{|c|}{ Low-Fe } \\
\hline & \multicolumn{2}{|c|}{ Glucose } & \multicolumn{2}{|c|}{ Fructose } & \multicolumn{2}{|c|}{ Glucose } & \multicolumn{2}{|c|}{ Fructose } \\
\hline & Mean & $\mathrm{SE}$ & Mean & SE & Mean & $\mathrm{SE}$ & Mean & $\mathrm{SE}$ \\
\hline Intake $(\mu \mathrm{g} / \mathrm{d})$ & 660 & 51 & $557^{\mathrm{a}}$ & 38 & $142^{b}$ & 11 & $125^{a b}$ & 11 \\
\hline Faecal output $(\mu \mathrm{g} / \mathrm{d})$ & 383 & 28 & 389 & 55 & $64 \cdot 5^{\mathrm{b}}$ & 10 & $71 \cdot 0^{\mathrm{b}}$ & 15 \\
\hline Absorption ( $\%$ of intake) & $41 \cdot 8$ & $4 \cdot 5$ & $29 \cdot 9^{\mathrm{a}}$ & $9 \cdot 7$ & $54 \cdot 4^{b}$ & $7 \cdot 2$ & $42 \cdot 5^{\mathrm{ab}}$ & $14 \cdot 0$ \\
\hline
\end{tabular}

a Significantly different from glucose for the same dietary Fe content, $P<0.025$.

' Significantly different from normal $F e$ for the same dietary monosaccharide, $P<0.025$.

* Because of different variances between the groups, even after log-transformation, ANOVA was not possible,

$\dagger$ For details of diets and procedures, see Table 1 and pp. 171-174.

1981), this should reduce $\mathrm{Fe}$ absorption. Indeed, apparent absorption of $\mathrm{Fe}$ was significantly lower in the fructose groups. The relationship, at a fixed Fe status, between soluble Fe concentration in the intestinal lumen and apparent Fe absorption is not known. Thus, it cannot be assessed to what extent the fructose-induced reduction in Fe absorption may be explained by the lowering of $\mathrm{Fe}$ concentration in the liquid phase of intestinal contents.

The observed fructose-induced impairment of Fe absorption is at variance with earlier reports. Fructose and $\mathrm{Fe}^{3+}$ can form soluble, stable complexes in vitro (Charley et al. 1963) and oral administration of such a complex has been shown to facilitate Fe absorption (Bates et al. 1972). $\mathrm{Fe}^{3+}$-fructose complexes can also be prepared in vitro, but only at high carbohydrate: Fe values (Charley et al. 1963). Possibly, Fe-fructose complexes were not formed in the gastrointestinal tract of our rats because the $\mathrm{pH}$ of the digesta and/or the $\mathrm{Fe}$ :fructose molar ratio were not suitable (Charley et al. 1963). The use of $\mathrm{Fe}^{3+}$ salts as the dietary Fe source and/or a different experimental design may explain the earlier observed sucrose-induced (Johnson \& Hove, 1986) and fructose-induced (Pabón de Rozo et al. 1986) stimulation of Fe absorption in rats. Johnson \& Hove (1986) compared sucrose with maize starch and used $\mathrm{Fe}_{2}\left(\mathrm{SO}_{4}\right)_{3}$ as the Fe source. Pabón de Rozo et al. (1986) added ${ }^{59} \mathrm{FeCl}_{3}$ to meals containing either glucose or fructose and determined the absorption of the label in rats.

The previously stated reasoning implies that the effect of fructose on $\mathrm{Fe}$ absorption depends on the Fe source in the diet. With $\mathrm{Fe}^{3+}$ salts, fructose may improve Fe absorption, which may relate to the formation of $\mathrm{Fe}^{3+}$-fructose complexes in the gastrointestinal tract. The present study using $\mathrm{FeSO}_{4}$ as the $\mathrm{Fe}$ source demonstrates that fructose $v$. glucose lowers $\mathrm{Fe}$ absorption in rats, which may relate to the decreased $\mathrm{Fe}$ concentration in the liquid phase of intestinal digesta. Why dietary fructose lowers this concentration is not known.

\section{REFERENCES}

Bates, G. W., Boyer, J., Hegenauer, J. C. \& Saltman, P. (1972). Facilitation of iron absorption by ferric fructose. American Journal of Clinical Nutrition 25, 983-986.

Charley, P. J., Sarkar, B., Stitt, C. F. \& Saltman, P. (1963). Chelation of iron by sugars. Biochimica et Biophysica Acta 69, 313-321.

Fields, M., Ferretti, R. J., Smith, J. C. Jr \& Reiser, S. (1984). The interaction of type of dietary carbohydrates with copper deficiency. American Journal of Clinical Nutrition 39, 289-295.

Hallberg, L. (1981). Bioavailability of dietary iron in man. Annual Reviews of Nutrition 1, 123-147. 
Holbrook, J., Fields, M., Smith, J. C. Jr, Reiser, S. \& Los Alamos Medical Research Group. (1986). Tissue distribution and excretion of copper-67 intraperitoneally administered to rats fed fructose or starch. Journal of Nutrition 116, 831-838.

Johnson, M. A. \& Hove, S. S. (1986). Development of anemia in copper-deficient rats fed high levels of dietary iron and sucrose. Journal of Nutrition 116, 1225-1238.

Landes, D. R. (1975). Influence of dietary carbohydrate on copper, iron and zinc status of the rat. Proceedings of the Society for Experimental Biology and Medicine 150, 686-689.

Lewis, C. G., Fields, M. \& Beal, T. (1990). The effect of various levels of fructose in a copper-deficient diet on Cu deficiency in male rats. British Journal of Nutrition 63, 387-395.

National Research Council (1978). Nutrient Requirements of Laboratory Animals. Washington, DC: National Academy of Sciences.

Pabón de Rozo, M., Van Campen, D. \& Miller, D. D. (1986). Effects of some carbohydrates on iron absorption. Archivos Latinoamericanos de Nutrición 36, 688-699.

Sørensen, E. W. (1965). Studies on iron absorption. II. Experiments with iron-deficient and non-deficient rats. Acta Medica Scandinavica 178, 385-392.

Wien, E. M. \& Van Campen, D. R. (1991). Ferric iron absorption in rats: relationship to iron status, endogenous sulfhydryl and other redox components in the intestinal lumen. Journal of Nutrition 121, 825-831. 